degradation are unavoidable challenges. It is hard to imagine a more successful illumination of those challenges than this exhibition.

Travelling exhibitions are money-losers. But this exhibition deserves to be seen beyond Los Angeles. Southern California is famous enough, thanks to Hollywood, for a presenta- tion of its problems to serve a purpose even outside the United States. Better still would be for local museums to adapt the exhibition, soliciting video narratives of foreseeable threats from their local citizens and leaders. Next stop Australia?

Philip Campbell is editor-in-chief of Nature.

\title{
Chemistry to die for
}

The Elements of Murder: A History of Poison by John Emsley

Oxford University Press: 2005.436pp.

£18.99, \$30

\section{Roger P.Smith}

The title is a bit of a put-on. In The Elements of Murder, John Emsley, a chemist and science writer, slowly works his way through the periodic table, discussing those elements that are toxic enough to have caused human poisonings, whether accidental, or as emphasized here, deliberate. Rather more amusing is the (unintentional?) quip in the introduction: "Murder by poison may be a dying art..."

The major thrust of this effort centres on what professional toxicologists invariably, but unsatisfactorily, classify as 'heavy metals. These are the electropositive natural constituents of the Earth's crust, with a density greater than 5 . The classification has always been unsatisfactory because it lumps together some 40 elements of wildly different acute or chronic toxicity, including some that have a very low toxicity, or are toxic but still required in small amounts for normal biological function. No toxicologist, however, would dispute the importance of mercury, arsenic and lead in

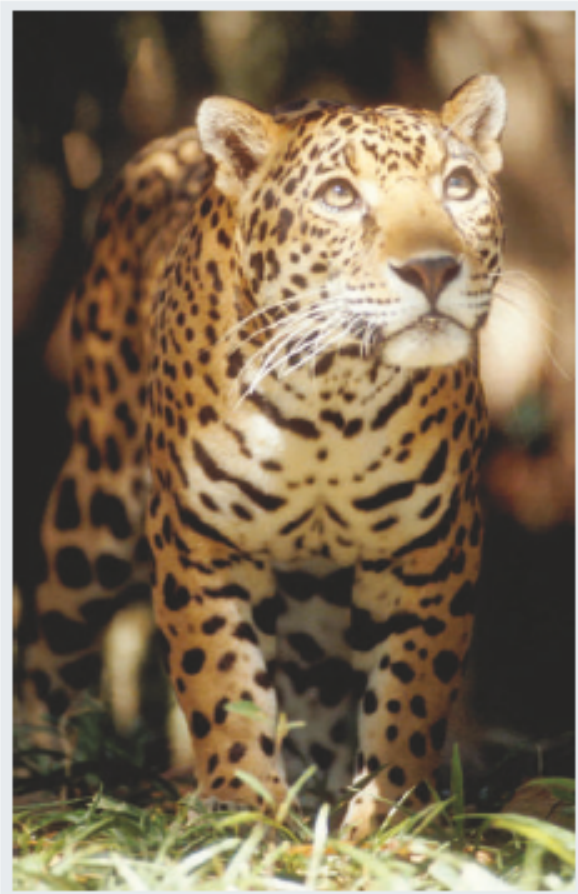

any work on poisons, and a great deal of attention is lavished on them here, together with antimony and thallium. Because Emsley excludes non-metallic organic compounds, the work is not a general history of poison.

The Elements of Murder is obviously a labour of love, but it is less certain whether a niche readership will emerge that will reciprocate the author's affection for the material. The book is both authoritative and meticulously researched, and I found remarkably little to quarrel with in the factual content. Emsley knows what he is talking about. The book's formidable girth includes an extensive bibliography, a brief appendix, a glossary and a useful index. But the lack of citations in the text will limit the book's use as a primary reference source. On the other hand, it is too technical and comprehensive to be a good beach read.

Emsley gives us much more than the collection of anecdotes about grisly murders that the title and dust-jacket seem to promise. Indeed, even the most ghoulish of readers will grow weary from the sheer number of cases reported. Because homicidal arsenic poisoning has been carried out with regularity since antiquity, there are many more examples for arsenic than for the other elements. One would think that a rather smaller group might have made the point. How many cases can one read about before imagining that one is personally experiencing the symptoms? I was surprised by the intimate details that Emsley has uncovered (and perhaps unfortunately chosen to include) about activities that were supposedly conducted in the greatest of secrecy so many years ago.

The book also includes detailed information on the amounts of the elements found in common foodstuffs, their industrial applications, common chemical reactions, distributions of the element in the body, methods of detection, common forms found in the environment, medical uses, and much more. It's not that this material is irrelevant, just that it is all a little too much. Tucked away into this mass of information are many fascinating tidbits. For example, can it be that thallium is one of the weapons of mass destruction supposedly concealed by Saddam Hussein? The book includes reports on the poisonings, alleged or authentic, occupational or sinister, of many famous people, such as Napoleon, Isaac Newton, Handel, Beethoven, King George III and others.

Toxicological dassifications always indude a 'miscellaneous' category, and the final chapter has such a group. It contains much shorter treatments of a few more heavy metals and some other assorted elements, many of which were never involved in homicides. But there is no mention of iron, which has caused many tragic accidental deaths.

This is a lovely book, but perhaps sitting down and reading it from cover to cover is not the best way to appreciate it.

Roger Smithis the Irene Heinz Given professor of pharmacology and toxicology emeritus, Dartmouth Medical School, Hanover, New Hampshire 03755, USA.

\section{Creatures and craters}

Whether you are planning an exotic vacation or looking for a location for your next field trip, two recently published books should provide some ideas.

Nature's Stranghold: The World's Great Wildlife Reserves by Laura and William Riley (Princeton University Press, $\$ 49.50, \mathbf{2 3 2 . 5 0 )}$ ) is a compendium of more than 600 of the world's wildilife reserves.

The book features reserves from 80 countries, giving details of such well knownones as America's Yellowstone National Park and Tanzania's Serengeti reserve, as well as lesser known specialistreserves such as Russia's Shulgan-Tash Zapovednik, which was setup to protect the last wild Burzyan honeybees in Russia. Vu Quangreserve in Vietnamis home to the Vu Quang ox - the firstnewmammal species reported for 50 years. The European bison was once nearly hunted to extinction but a remnant herd, originally protected by Hitler's deputy
Hermann Göring, now inhabits Poland's Bialowieza National Park and a transborder reserve in Belarus. And the endangered jaguar (see picture) finds safe haven at the Cockscomb Basin Jaguar Sanctuary in Belize.

This illustrated book gives details of what to see and when to visit for each of the reserves featured, making it an interesting read whether you are planning a trip or are just an armchair traveller.

More intrepid travellers might find The Volcano Adventure Guide (Cambridge University Press, $£ 30, \$ 50$ ) more exciting. Rosaly Lopes' book gives advice on planning a visit to an active volcano, and has detailed guides to 42 of the world's most spectacularexamples.

With chapters on the types of eruption as well as safety and survival rules, this is another book that should interest those staying at home as well as amateur and professional volcanologists alike. 